\title{
Analisis Kritik Sastra Feminis dalam Cerpen Catatan Hati Yang Cemburu Karya Asma Nadia
}

\author{
Suaibatul Aslamiyah ${ }^{1}$, Suci Nadilla Aryandini ${ }^{2}$, Cindy Aprilia Pratami ${ }^{3}$ \\ Pendidikan Bahasa dan Sastra Indonesia, Fakultas Ilmu Pendidikan, \\ Universitas Muhammadiyah Jakarta \\ Suaibatulaslamiyah866@gmail.com, Sucinadilla9@gmail.com, \\ Cindyapriliaprat@yahoo.com
}

\begin{abstract}
Art has opened the eyes of the world throught literary works that record the history of a writing. Also the subject of women's affairs is subject to an author's reference to the problem of a sense of injustice. Such views have been discussed to voice gender equality and to seek efforts to overcome those problems. Nadia's asthma is one of the authors who attempt to awaken women to the patriarchate system that has been going on. His works consistently incorporate such universal values as equality in various fields, human freedom, and tolerance so that his readers can adopt the value of life. In addition, she was actively involved in social media as a means of channeling her mind. The twitter feed says some of the people were repressed. Seeing the account encourage him to make a book and then be poured into a storybook of several different stories and in which one of the women's true account $t$ with the tittle of a jealous heart note. The study used qualitative descriptive methods with the theory of feminist literary criticism.
\end{abstract}

Keywords: Women; Asma Nadia; author; feminist; gender equality.

\section{Intisari}

Seni telah membuka mata dunia melalui karya sastra yang mencatat sejarah dari sebuah tulisan. Perihal persoalan perempuan juga tak luput dituangkan oleh pengarang yang menyinggung masalah dari rasa ketidakadilan. Pandangan demikian telah dibahas untuk menyuarakan kesetaraan gender dan mencari upaya mengatasi problematika tersebut. Asma Nadia salah satu penulis yang mencoba menyadarkan kaum perempuan untuk bangkit dari sistem patriarki yang selama ini terjadi. Melalui beberapa karyanya selalu menyertakan nilai universal, seperti persamaan hak di berbagai bidang, kemerdekaan manusia, dan toleransi agar pembacanya bisa mengambil nilai-nilai kehidupan. Selain itu, ia aktif di media sosial sebagai sarana menyalurkan pikirannya. Dalam twitternya tersebut terdapat cerita beberapa orang yang mengalami represi. Melihat kisah itu mendorongnya untuk membuat buku lalu dituangkan menjadi sebuah cerpen yang terdiri dari beberapa cerita yang berbeda dan diambilah salah satu kisah nyata seorang perempuan dengan judul Catatan Hati yang Cemburu. Penelitian ini menggunakan metode deskriptif kualitatif dengan teori kritik sastra feminis. 
Kata kunci: Perempuan; Asma Nadia; feminis, pengarang, feminis, kesetaraan gender.

\section{Pendahuluan}

Sastra adalah suatu kegiatan kreatif dari karya seni, sedangkan studi sastra adalah cabang ilmu pengetahuan (Wellek dan Werren, 2016:3). Mencipta suatu karya merupakan bagian dari usaha dalam menyampaikan emosi dan pesan pengarang dari apa yang dirasa. Seni kreatif ini melibatkan manusia sebagai objeknya dan bahasa sebagai sarananya. Karya sastra berupa peninggalan bersejarah bagaikan artefak atau benda mati yang mempunyai makna dan objek estetik bagi manusia. Sebagaimana seorang arkeolog yang memberikan makna terhadap sebuah objek. Begitu pula dengan sastra, pemberian makna dilakukan dalam kegiatan kritik sastra. Kritik sastra memiliki aspek pokok berupa analisis, interpretasi (penafsiran), dan evaluasi atau penilaian (Pradopo dalam Anisah, 2018:2).

Sastra merupakan bagian dari cerminan kehidupan yang dituangkan oleh seorang penulis berdasarkan pengalaman pribadi maupun dari orang lain. Seorang penulis berusaha membedah aspek kehidupan yang dilukiskan melalui karyanya. Lalu di interpretasi dan dikaitkan oleh beberapa ilmu yang dimilikinya untuk menghasilkan sebuah karya yang indah. Walau demikian, sastra tidak hanya untuk dinikmati penulis maupun pembaca tetapi karya tersebut dinilai kembali melalui salah satu bidang ilmu sastra yaitu kritik sastra. Kritik sastra bagian dari penilaian untuk melihat kekurangan maupun kelebihan dari sebuah karya sastra tanpa menyudutkannya. Berusaha menyelidiki karya sastra dengan menganalisis, memberi pertimbangan baik buruknya karya sastra atau bernilai tidaknya karya sastra tersebut.

Adapula cara untuk mandapatkan gambaran yang jelas mengenai kritik sastra pada suatu karya yaitu berkaitan dengan judgement, valuation, proper understanding, recognition, statement giving valuation and rise in value (Devi, 2019:14). Untuk memberi penilaian perlu melihat karya tersebut secara keseluruhan. Pada dasarnya dalam penilaian mencakup tiga paham penilaian. Penilaian pertama yaitu relativisme yang menghendaki tidak adanya penilaian lagi. Penilaian kedua adalah paham penilaian absolut berdasarkan paham-paham, aliran-aliran, politik, moral ataupun berdasarkan ukuran-ukuran tertentu. Penilaian ketiga yaitu penilaian perspektif dari berbagai sudut pandang dengan 
menunjukan karya sastra pada waktu terbitnya dan nilai-nilai karya sastra itu pada masa berikutnya (Pradopo, 2011:49)

Dokumen sastra yang digunakan berupa cerpen karya Asma Nadia yang berjudul Catatan Hati Yang Cemburu. Cerpen ini terdiri dari 21 kisah berbeda dari orang yang berbeda pula. Cerpen atau cerita pendek sebuah karya fiksi bersifat imajinatif dengan mengungkapkan satu masalah secara singkat dan padat dan mengandung komponen atau struktur berupa alur, latar, penokohan, sudut pandang, gaya bahasa, tema serta amanat (Muhardi dalam Puspitasari, 2017:3)

Dari beberapa kisah dalam cerpen tersebut mengangkat satu kesimpulan yaitu tentang masalah percintaan dalam sebuah rumah tangga. Buku ini memberikan sebuah pandangan berdasarkan kisah nyata mengenai curahan hati para istri yang cemburu terhadap sebuah objek tertentu. Dalam hal ini, memberikan pembelajaran agar bijak menata hati dan emosi serta dapat mengenali rasa cemburu dengan objek dan penanganan yang tepat.

Seorang Asma Nadia penulis perempuan Indonesia yang berasal dari aceh dengan nama lengkap Asmarani Nadia Rosalba. Mempunyai latar belakang dari keluarga yang religius membawanya pada corak yang berbeda untuk setiap karyanya. Kultur budaya ini yang selalu ditampilkan memberikan pesan agamis kepada pembaca. Kegemarannya dalam menulis sudah ditekuninya sejak kecil. Sewaktu kuliah ia mencoba fokus untuk menulis dan menghasilkan karya pertamanya berupa cerpen yang dimuat dimedia massa berjudul Surat Buat Asadullah di Surga.

Berangkat dari seorang penulis adalah merupakan profesi yang turun menurun dari sang kakek dan kakaknya. Mereka sama-sama memiliki minat dalam satu bidang yang sama yaitu tulis menulis. Membaca beberapa karyanya sebagai seorang muslimah terlihat kepiawaiannya menata kalimat demi kalimat mengandung unsur keselarasan yang dipadu dengan nilai keislaman. Perbincangan mengenai perempuan dari pandangan islam mempunyai derajat yang mulia. Tetapi sepenuhnya, berkaca dari realitas kehidupan tidak demikian. 
Fenomena yang terjadi dan dihadapi oleh para perempuan terwakilkan lalu digambarkan dari beberapa cerita dari cerpen ini. Permasalahan tentang cinta memang rentan terjadi dalam suatu hubungan apalagi kehidupan rumah tangga. Konfik antara pasangan suami dan istri bukanlah suatu hal yang asing. Semua akan kembali normal jika menemukan solusinya. Apa jadinya bila permasalahan ini tidak mendapat titik temu. Posisi perempuan selalu dilemahkan dan dinomor duakan. Lelaki seakan mempunyai kendali atas hidup pasangannya. Sebagai seorang penulis, Asma Nadia ingin mendemonstrasikan untuk mengembalikan kedudukan perempuan sebagai sesuatu yang dihormati dan menyadarkan para lelaki khusunya suami yang harus lebih menjaga amanatnya terhadap janji yang telah diikrarkan dalam pernikahan.

Segala daya dan upaya kaum perempuan untuk mengambil hak-haknya kembali dituangkan dalam sebuah gerakan yang bernama feminisme. Feminisme merupakan idiologi yang meluas ke seluruh dunia. Feminisme membahas tentang wanita yang mampu melakukan banyak hal tanpa bantuan lelaki. Paham ini kemudian berkembang pada tahun 1960an sebagai teori kebudayaan kontemporer dengan analisis mencakup ekonomi, politik dan juga sosial (Devi, 2019:102). Menurut Moelino (dalam Buana, 2009:6) feminisme adalah sebuah gerakan perempuan untuk menuntut persamaan hak sepenuhnya dan menghilangkan pandangan terhadap gender yang dimiliki. Menurut Nancy (dalam Astuti, 2018:3) menyatakan feminisme mengandung tiga komponen pengertian yaitu suatu keyakinan tidak ada perbedaan yang berdasarkan seks, dalam masyarakat telah menjadi konstruksi sosial yang merugikan perempuan, dan menggugat perbedaan yang mencampurkan gender dan seks hingga perempuan dijadikan kelompok sendiri.

Feminisme itu sendiri membentuk kesadaran yang dibangun oleh pengalaman perempuan yang khas tentang kebenaran, pengetahuan dan kekuasaan. Untuk menjawab masalah dalam kritik sastra feminis terdiri dari beberapa perspektif. Pertama berupa kritik ideologis yang melibatkan perempuan dari gambaran stereotip dalam karya sastra. Kedua perspektif ginokritik yang memusatkan pengarang perempuan berkaitan dengan kepengarangannya yang meliputi tema, sejarah, kreativitas, telaah menulis dengan karyanya (Adji, 2003: 2). Berdasarkan landasan ini yang dipakai untuk kritik sastra feminis terhadap cerpen Catatan Hati Yang Cemburu yaitu kritik ideologis dengan memperhatikan penyebab rasa cemburu yang dimiliki oleh pasangan perempuan atau istri. 
Perenungan ini dapat kita selidiki bagaimana seorang suami melakukan suatu kegiatan yang dapat membuat istrinya cemburu. Banyak faktor yang menjadi pendorong lelaki untuk melakukan sesuatu hal yang negatif terhadap pasangannya. Asma Nadia ingin menjadikan cerpen ini sebagai bahan untuk referensi bacaan suami dalam menjaga perasaan istri. Begitu pula bacaan untuk para istri agar terbebas dari cemburu yang berlebih.

\section{Metode Penelitian}

Bersumber dari data yaitu berupa teks cerpen Catatan Hati Yang Cemburu karya Asma Nadia terbitan AsmaNadia Publishing House, Jawa Barat pada 2012. Penelitian ini bertujuan untuk menemukan dan mendeskripsikan wujud perspektif tindakan perlakuan laki-laki terhadap perempuan dalam cerpen Catatan Hati Yang Cemburu. Berdasarkan tujuan tersebut, maka metode yang digunakan dalam penelitian ini menggunakan penelitian deskriptif kualitatif. Pendekatan deskriptif kualitatif dalam penelitian ini adalah suatu prosedur penelitian dengan hasil sajian data deskriptif berupa tuturan pengarang dalam cerpen Catatan Hati Yang Cemburu.

Teknik analisis data adalah usaha menemukan secara sistematis data yang didapat dari hasil pengamatan dan dokumentasi dengan cara mengorganisasikan data ke dalam kategori, menjabarkan ke tiap unit-unit, mencampurkan kebeberapa pengertian untuk menyusun ke dalam pola, memilih mana yang penting, dan membuat kesimpulan sehingga mudah dimengerti oleh peneliti maupun orang lain (Sugiyono dalam Anisah 2018:7).

Adapun teknis analisis data dalam penelitian ini adalah teknik deskriptif dan analisis isi. Penelitian kualitatif adalah jenis penelitian yang dilakukan dengan tidak mengutamakan pada angka-angka tetapi menggunakan penghayatan terhadap interaksi antar konsep yang sedang dikaji secara empiris. Pendekatan deskriptif kualitatif dalam penelitian ini adalah suatu prosedur penelitian dengan hasil sajian data deskriptif berupa tuturan pengarang dalam cerpen Catatan Hati Yang Cemburu.

\section{Hasil dan Pembahasan}

Pengkhianatan Kepada Perempuan dalam Kumpulan Cerpen CHYC 
Pengkhianatan berasal dari kata khianat yang mempunyai arti perbuatan tidak setia kepada manusia lain. Pengkhianatan adalah bentuk tindakan yang bertentangan dengan janji dan menyakiti hati orang yang telah dijanjikannya. Kumpulan kisah dalam cerpen Catatan Hati Yang Cemburu terdiri dari dua puluh satu cerita yang berbeda. Asma Nadia mengkombinasikannya dengan beberapa cerita secara berurutan. Semua cerita mengenai rasa cemburu para istri terhadap pasangannya yang melakukan pengkhianatan. Pernikahan merupakan bersatunya dua insan dengan jenis kelamin berbeda dengan kesepakatan membangun rumah tangga untuk hidup bersama atas cinta yang diikrarkan pada proses nikah dan diizinkan secara agama dan negara. Manakala seorang dari salah satu pasangan yang mengingkar janji maka orang tersebut telah berkhianat. Perbuatan tersebut tidak akan terjadi bila mempunyai sikap setia dan memiliki landasan keimanan yang kuat. Biasanya orang yang melakukan hal ini yaitu lelaki atau seorang suami. Kejadian ini telah diungkapkan dari cerpen tersebut yang menceritakan beberapa permasalahan dalam rumah tangga. Potret ketidakharmonisan tergambarkan melalui curahan hati para istri yang mengungkapkan peristiwa yang dialami secara langsung. Perhatikan kutipan paragraf berikut ini:

"Aku baru tergelitik ketika adikku bercerita tentang komentar-komentar ramahmu di halaman Facebook seorang perempuan. Ah, naifkah aku yang waktu itu tak menghiraukan keraguan adik? Atau keyakinan bahwa kau mencintaiku dan hanya aku yang membutakan mata?"(Catatan Hati Yang Cemburu, hal 175).

Pada kutipan di atas mengandung sinopsis perihal sepasang suami istri yang sudah lima tahun membangun rumah tangga. Mereka memiliki tiga orang anak sebagai pelengkap kebahagian hidup. Perasaan sang istri kepada suami akhir-akhir ini seperti tidak enak. Ada yang tak beres dengan suaminya. Prasangka buruknya itu tak digubris sampai anggota keluarga atau adik dari sang istri juga curiga kepada suami kakaknya. Ia mencoba membantu untuk menyelidiki kasus ini. Tak disangka ternyata firasat buruknya itu benar terjadi. Suaminya telah berkhianat dengan perempuan lain ketika malam takbiran. Bukan tangis kebahagiaan dalam merayakan tahun baru islam melainkan tangis karena rasa kecewa yang amat mendalam kepada pasangannya tersebut. Pengarang cerpen ini ingin memberikan peristiwa yang familiar terjadi dalam kehidupan. Penggunaan bahasa pun sangat mudah dimengerti dengan menggunakan kata-kata yang sederhana. Ada beberapa penekanan kalimat yang menunjukan sebuah tujuan untuk menyadarkan wanita supaya 
cermat memantau situasi yang memang sudah dirasa meragukan. Perlakuan ini juga ada pada paragraf berikut:

\begin{abstract}
"Begitulah mataku mempergokinya, usai jam kantor masih sibuk chatting. Masih sambil mengamati tingkah lakunya dari jauh, aku mengirim pesan singkat ke HPnya, bertanya apakah dia masih di kantor atau sudah keluar. Jawabannya adalah kebohongan. Suami bilang dia masih di kantor tapi lagi sibuk buat laporan. Jadi tidak bisa diganggu sama sekali. Padahal aku lihat dia sedang senyum-senyum. Sangat kelihatan keceriaannya. Benar-benar bahagia" (Perempuan yang Chatting denganmu, hal 31).
\end{abstract}

Potongan paragraf itu menjelaskan curhatan seorang istri yang merasa curiga dengan tingkah laku suaminya. Semenjak suaminya itu bermain aplikasi Facebook ada yang berubah dari dirinya, dia asik dengan dunianya sendiri. Melupakan tanggung jawabnya menjadi suami, jarang menyapa anak-anaknya dan mengabaikan kehadiran sang istri yang dahulu ia cintai. Keretakan hubungan tersebut membawa emosi yang terlarut lama. Ada keinginan untuk berpisah dengan sang suami. Sifatnya tak berubah bahkan semakin menjadi. Sang istripun mencoba mencari jalan yang terbaik untuk rumah tangga mereka. Memberi kesempatan kepada selingkuhannya tersebut untuk menikah dengan suaminya agar terhindar dari zina. Ternyata pernyataan dari pihak perempuan itu tidak berkenan, ia menganggapnya hanya buat semata saja, tak lebih. Suaminyalah yang sangat gatal dengan perempuan itu. Persoalan rumah tangganya terus berlanjut. Tak tahan dengan kelakuan hina suaminya ia berkeinginan menyudahi dengan menggugat cerai ke pengadilan agama. Sang istri terus meminta petunjuk kepada allah dengan mendekatkan diri dan melakukan solat malam. Tujuan pengarang membuat tulisan ini tak terlepas dari mengangkat keinginan dan mensejahterakan hak serta derajat wanita untuk lebih dihormati. Pada penggalan kisah diatas menyatakan kebohongan suami dalam menutupi pengkhianatan. Pihak istri sudah mengetahui hal tersebut. Jika demikian, maka istri dapat berkomunikasi langsung kepada suami dan membicarakan secara baik-baik. Menghilangkan kecurigaan yang berlebih untuk mengontrol emosi dalam diri.

Halaman pertama pada cerita tersebut, Asma Nadia memberikan sebuah hadist yang berkenaan pada pembahasan berikut "Saad bin Ubaidah radhiallahuanhu berkata, sekiranya aku melihat seorang laki-laki bersama dengan istriku, niscaya akan kutebas ia dengan pedang. Ucapan itu akhirnya sampai kepada Rasulullah lalu beliau 
shallallahu'alaihi wa sallam bersabda. Apakah kalian merasa heran terhadap kecemburuan Sa'ad? Demi allah aku lebih cemburu daripadanya, dan allah lebih cemburu daripadaku". (HR Al-Bukhari)

Hadist tersebut menerangkan bahwa rasa cemburu memang wajar terjadi. Rasa itu timbul karena ada sebabnya. Apalagi seorang perempuan yang memiliki intensitas perasaan yang kuat terhadap sesuatu. Ini memberikan gambaran bahwa memiliki sifat cemburu memang sah-sah saja terjadi selama tidak melewati batas cemburu. Pada zaman rasul para suami sangat menjaga diri agar keluarganya tetap utuh. Pembelajaran yang dapat diambil dari hadist ini yaitu sebagai manusia kita harus memiliki komitmen terhadap sebuah perjanjian. Pernikahan bukanlah suatu ikatan percintaan yang dapat dipermainkan. Janganlah mudah terbawa oleh kesenangan sesaat yang membawa kesengsaraan. Relativitas cerita yang diangkat pengarang untuk meminimalisir kehancuran dalam rumah tangga. Diberikan contoh-contoh yang mungkin suatu saat akan terjadi dalam hidup. Inilah pelajaran yang dapat diambil oleh kedua pihak antara penulis maupun pembaca untuk dapat mencari solusi yang terbaik bila masalah tersebut menghampiri kita.

\section{Hasrat Ingin Memiliki Perempuan Lain}

Manusia pada hakikatnya memang tidak akan pernah puas dengan apa yang sudah dimilikinya. Ketidakpuasan itu yang menuntut seseorang untuk melakukan apapun demi mendapatkan sesuatu yang diinginkan. Segala hal dilakukan bahkan dapat menyakitkan orang lain sekalipun. Gambaran ini yang terjadi dalam beberapa kisah yang tulis Asma Nadia dan penyumbang cerita berdasarkan pengalaman hidup pribadi. Seperti paragraf berikut:

"Ya Allah mas, apa yang sudah kita bangun selama ini akan hancur. Rasanya saya tidak sanggup berbagi kebahagiaan dengan hadirnya wanita dan anak-anak yang lain". (Saat Mas Ingin Menikah lagi, hal 185)

Pengakuan dari seorang istri bernama Rani yang sudah berumah tangga selama tiga belas tahun harus mendapatkan pernyataan pahit dari suaminya yang ingin menikah dengan teman perempuannya. Dalam islam memiliki istri lebih dari satu memang diperbolehkan karena bagian dari ibadah akan tetapi, hukum tersebut juga memiliki aturan bahwa istri pertama harus bersedia lahir batin, seorang lelaki yang ingin berpoligami harus adil membagi kasih sayang dan menambah kewajiban yang dinafkahi. Jika lelaki itu tidak 
sanggup maka jangan melakukan hal tersebut. Rani awalnya keberatan dengan pernyataan suaminya, ia berdiskusi dengan temannya. Kemudian Rani dinasihati oleh temannya, bila itu pilihan yang terbaik maka lakukanlah, ikhlaskanlah, suami adalah milik allah serahkan saja pada-Nya. Setelahnya, ketika semua sudah bersedia suaminya pergi untuk meminta izin kepada Rani untuk pergi ke rumah pihak perempuan yang akan dinikahinya lagi tetapi, terdapat keraguan dihati suaminya sehingga hal tersebut tidak terjadi. Cinta adalah sebuah rasa yang dianugrahkan oleh allah kepada setiap hambanya. Segala hal yang ada didunia tidak abadi, begitupun dengan pasangan. Kejadian yang rumit ini tak dapat diterima semua wanita hanya wanita yang bersabarlah dan memiliki iman yang kuat yang dapat melaluinya. Pada zaman sekarang hal tersebut adalah sebuah kebaikan. Tetapi, ada beberapa lelaki yang menyalah gunakan aturan yang telah allah tetapkan. Semua perlu pertimbangan yang matang untuk bisa menjadi imam yang baik serta adil kepada istriistrinya. Janganlah bermain dengan sesuatu yang sakral ini. Karena semua yang dilakukan di dunia ada pertimbangannya di akhirat kelak. Berikut kisah lain:

"Aku tahu aku tidak cantik. Aku tahu aku jauh dari cantik bila dibandingkan dengan artis itu”.(Cinta yang Pernah Singgah di Hati Abang, hal 161).

Menceritakan seorang istri yang telah gagal dalam menjalin hubungan rumah tangga karena suaminya yang lebih memilih pergi untuk perempuan lain. Kehidupannya berubah setelah bercerai dengan suaminya. Masalah percintaan baginya sudah sirna, takut kejadian masa lalunya terulang, tak ingin disakiti lagi sebab ia trauma hal tersebut sudah pernah terjadi dengan dirinya, ibunya, bahkan sampai neneknya yang harus bercerai dengan kakeknya. Tak diduga, beberapa tahun kemudian ia bertemu dengan lelaki yang jauh berbeda dengan mantan suaminya. Mempunyai sifat baik dan setia yang membuatnya terdorong membangun rumah tangga kembali. Karena memiliki bidang pekerjaan yang sama yaitu memotret terkadang mereka bertemu. Saat diperjalanan suaminya menunjukan hasil potretan dan memuji kecantikan istrinya tetapi suaminya tersebut lebih tertarik dengan model yang memiliki paras cantik dan rupawan. Mendengar perkataan suami, membuatnya marah dan cemburu sampai kemudian pertengkaran tersebut usai. Rupa bukanlah sesuatu yang abadi. Menjadi cantik ataupun tampan itu adalah sebuah tampilan yang dapat berubah suatu saat. Keimananlah yang menjadi tombak kekuatan. Menerima kekurangan maupun kelebihan pasangan sebuah hal yang berharga atas cinta yang abadi. Dari kisah yang dituangkan oleh penulis menjadi renungan sehingga melahirkan kritikan 
terhadap budaya yang berlaku saat itu karenanya segala yang dilakukan oleh perempuan dalam cerita ini adalah dilatari oleh tradisi keterpasungan perempuan yang mengatasnamakan hukum ataupun agama.

\section{Simpulan}

Meraih emansipasi wanita dalam sejarah dunia memiliki proses yang panjang hingga berkembang sampai saat ini. Memperjuangkan kedudukan itu perlu pengorbanan sehingga perempuan dapat mempunyai kedudukan dan terbebas dari tekanan pendidikan, ekonomi, sosial politik dan lainnya. Pola pikir itu bagian dari aliran feminis yang dipelopori oleh Virginia Wolf pada awal abad ke 20. Sebelum adanya gerakan tersebut perempuan selalu dibatasi dalam berbagai bidang kehidupan tetapi kini hal tersebut sudah jarang terjadi dan semua dapat menghirup kebebasan dunia.

Topik utama dalam kajian tersebut yaitu perempuan, berbicara soal rumah tangga untuk menjadi istri adalah bagian dari pilihan manusia. Dalam agamapun sesuatu yang dimuliakan untuk menjaga kehormatan dan melindungi diri dari kejahatan. Laki-laki menjadi kepala rumah tangga yang memiliki kewajiban penuh menjaga istri dan anakanaknya bukan malah sebaliknya. Potret masalah yang dituangkan Asma Nadia adalah bumbu percintaan dalam hubungan rumah tangga. Keharmonisan diraih untuk mencapai keluarga yang bahagia, menghindari perselisihan dan menyelesaikan secara baik-baik. Kenali pasanganmu, kenali dirimu dan pandailah dalam menjalani hidup.

Masalah-masalah tersebut yang memberikan pembelajaran bagi penulis maupun pembaca untuk lebih berhati-hati dalam bertindak. Jangan mudah mengambil keputusan saat sedang marah dan bijak dalam menata hati. Mengola perasaan juga perlu diterapkan untuk menjauhi diri dari segala yang tidak diinginkan. Cemburu adalah sebuah rasa yang maklum terjadi kepada semua orang asalkan jangan berlebihan dan malah membahayakan oleh karena itu, sebagai pasangan khususnya laki-laki harus lebih peduli kepada istrinya dan jauhi dari prilaku berkhianat dan juga hasrat yang bergejolak untuk memiliki perempuan lain.

\section{Daftar Pustaka}

Adji, Peni. 2003. Karya Religius Danarto Kajian Kritik Sastra Feminis. Jurnal Humaniora. 15(1):2 
Anisah, Nur dkk. 2018. Nilai Moral Tokoh Anak dalam Film Hafalan Shalat Delisa. Jurnal Fisip Unsyiah. 3(1):7

Anisah, Zulfatun. 2018. Realitas Kehidupan Islami dalam Novel Surat Kecil untuk Tuhan Karya Agnes Devanor (Kajian Mimetik). Jurnal Pendidikan Islam. 3(1):2

Astuti, Puji dkk. 2018. Ketidakadilan Gender Terhadap Tokoh Perempuan dalam Novel Genduk Karya Sundari Mardjuki Kajian Kritik Sastra Feminisme. Jurnal Ilmu Budaya. 2(2):3

Buana, Cahya. 2009. Sejarah, Teori dan Aplikasi Kritik Sastra Feminis. Jurnal Al-Turas. 15(3): 6

Devi, Soviana, Wika. 2019. Teori Sastra. Jakarta: CV Al Chalief.

Nadia, Asma. 2012. Catatan Hati Yang Cemburu. Depok: AsmaNadia Publishing House.

Pradopo, Rachmat Djoko. 2011. Prinsip prinsip Kritik Sastra. Yogyakarta: Gadjah Mada University Press.

Puspitasari, Anggun. 2017. Hubungan Kemampuan Berpikir Kreatif dengan Kemampuan Menulis Cerpen. Jurnal SAP. 1(3):3

Wellek, Rene dan Austin, Werren. 2016. Teori Kesusastraan. Jakarta: Gramedia. 